\title{
Physiological aspects of winter wheat selection for adaptability
}

\author{
Khomenko L. \\ Institute of Plant Physiology and Genetics of NAS of Ukraine \\ 31/17 Vasylkivska Str., Kyiv, 03022, Ukraine \\ e-mail: lidole@ukr.net \\ ORCID: 0000-0002- 3776-6208
}

Goal. Ta assess the varieties of winter wheat collection on the basis of drought resistance in the initial stages of seed germination in the solution of sucrose, which corresponds to a pressure of $16 \mathrm{~atm}$, and during grain filling by the coefficient of realization of ear productivity potential. To determine the concentration of the cell juice on the flag leaf of plants in the earing phase, and to establish the resistance of different winter wheat varieties to drought. Methods. Laboratory, field, statistical. Results. Varieties of winter wheat grown in collection nurseries were divided into 2 groups according to the level of productivity and direction of use. These included 19 varieties of selection of the Institute of Plant Physiology and Genetics (IPPG) of the National Academy of Sciences of Ukraine (Kyiv selection), and 14 varieties of southern regions of Ukraine (Southern selection). During the evaluation of varieties of the collection of IPPG it was found out that in the early stages of seed germination in the solution of sucrose, which corresponds to a pressure of $16 \mathrm{~atm}$, the level of drought resistance of varieties of Southern selection was $7.4 \%$ higher than Kyiv. Over the past 3 years, the average concentration of cell juice in varieties of Kyiv selection was $2 \%$ lower than in the South ones. The strong relationship ( $\eta \pm P 95=0.74 \pm 0.12)$ was found between the level of drought resistance of collection varieties in the early stages of seed germination in the solution of sucrose 16 atm from the concentrations of cell juice of the flag leaf in the phase of earing wheat. With a record abnormal heat and drought in the period of grain filling in 2019, the varieties of Kyiv selection realized their genetically determined productivity potential by a factor of 4.0 better than the varieties of the Southern selection. Varieties with the high coefficient of realization of ear productivity potential were selected: Favorytka - 4.6; Bohdana -5.4 ; Kalancha -5.8 , and Darunok Podillia - 6.1. Conclusions. It is proved that in the early stages of germination of wheat seeds in the solution of sucrose, which corresponds to a pressure of $16 \mathrm{~atm}$, the level of drought resistance of varieties has the strong relationship $(\eta \pm P 95=0.74 \pm 0.12)$ with the concentration of cell juice of the flag leaf in the earing phase of wheat. It was found out that with the record abnormal heat and drought in the period of grain filling in 2019 , winter wheat varieties of Kyiv selection $2.5 \%$ better realized their genetically determined ear productivity potential. Highly drought resistant and highly productive varieties of IPPG are distinguished: Favorytka, Bohdana, Kalancha, and Darunok Podillia.

Key words: Triticum aestivum L., varieties, drought resistance, concentration of cell juice, productivity, ear.

$$
\text { DOI: https://doi.org/10.31073/agrovisnyk202010-05 }
$$

Improving productivity of the crops, among which winter wheat (Triticum aestivum L.) is the main food crop, remains a strategic objective of Ukraine's agricultural sector [1]. Contemporary climate change, which has a significant impact on agricultural production, is making adjustments to the objectives.

Extreme temperatures of changing climatic conditions are one of the most common abiotic adverse factors. Increasing the air temperature causes droughts, which increases the evaporation of water from the soil surface and induces additional stress factors that can greatly affect the required mineral nutrition requirements [2] and, in general, productive crop processes [3].

Thus, in Ukraine in recent years there is a steady tendency to decrease the annual rainfall [4] and the presence of droughts during grain filling.

Drought causes a number of physiological, biochemical and molecular changes at the cellular level [5] and suppresses plant photosynthesis [6]. Environmental stress (especially drought) leads to the accumulation of soluble carbohydrates and free amino acids as well as antioxidant compounds. These low molecular weight compounds are dissolved in water and are a part of the cellular juice of plants. They are non-toxic and protect cellular components from damage and degradation [7]. The cellular juice of plants contains spare proteins. The chemical composition and amount of cellular juice substances may vary and depend on the type of cells, tissues, plant genotype, their physiological state, and the effects of environmental factors [8].

Therefore, in the current climate change, the most actual problems of breeding and production of grain of the agricultural plants include finding out the mechanisms of plant resistance to adverse 
environmental conditions and creation of new varieties with high productivity, with increased levels of adaptability and grain quality.

Purpoe of research is to evaluate winter wheat varieties on the basis of drought resistance in the initial stages of seed germination and during grain filling by the factor of realization of the ear productivity. To determine the concentration of cellular juice of the flag leaf of the plants in the germination phase and to establish a connection with the dry resistance of winter wheat varieties.

Materials and methods. The research was conducted in the fields of the experimental farm of IPPG, NAS of Ukraine, Glevakha town, Vasylkiv district, Kyiv region. The material was mild winter wheat varieties grown in the comparative trial collection nursery during 2015-2019.

The establishment of the experiment with wheat varieties was carried out according to the method of examination of plant varieties of the group of cereals for suitability for distribution in Ukraine [9]. The meteorological and actual average weather conditions were used according to the weather archive from the website «Pogoda i klimat» (http://www.pogodaiklimat.ru).

The concentration of cellular juice of winter wheat varieties was determined in the hatching phase with a selection of 3 pieces of flag leaf from the main stem of plants on the device RL 3 (Made in Poland).

The level of drought resistance of cultivar samples at the initial stages of seed germination was determined on sucrose solution, which corresponds to the pressure of $16 \mathrm{~atm}$, according to the method of Kozhushko MM [10]. The evaluation of the resistance of winter wheat varieties to drought was determined in the field by the coefficient of realization of the potential productivity of the ear (the difference of the ear weight measured with the ear weight in the flowering phase) [10].

The experiments were repeated 3-4 times. Statistical processing of the results was performed according to the method of Dospekhov BA [11] using AtteStat software (http://attestatsoft.narod.ru).

The climatic conditions of the Kyiv region in June 2015-2019 were characterized by an increased temperature regime with a small monthly rainfall of $57 \%$ of the norm during these years (Fig. 1).
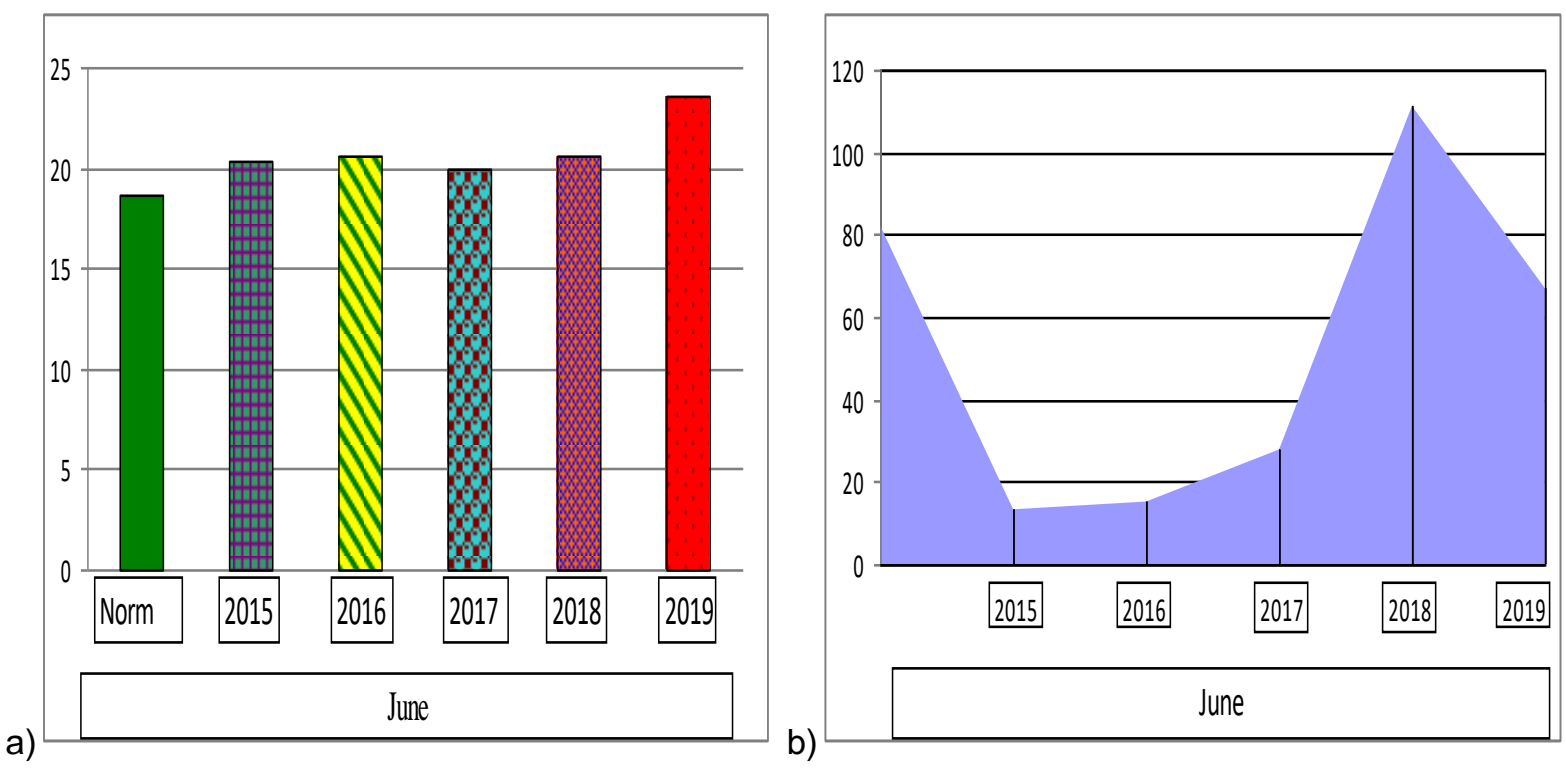

\section{Fig.1. The climatic conditions in June 2015-2019 during grain filling of winter wheat in the research area: $a$ - the average air temperature, ${ }^{\circ} \mathrm{C} ; \mathrm{b}$ - the rainfall number per month, $\mathrm{mm}$}

The data obtained show that during the last 5 years, the average monthly air temperature during

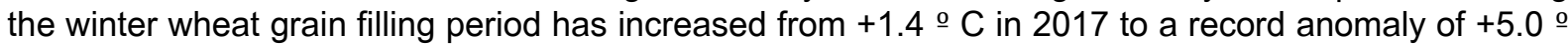
$C$ in 2019. Rainfall in June 2015-2017 was a slight of 13-28 mm (or 16-35\% of norm) and with intense local character of 111 and $67 \mathrm{~mm}$ in 2018 and 2019. But the high temperatures quickly evaporated them from the soil during the day, not providing sufficient moisture to the plants.

Results of research. In evaluating the varieties of the IPPG Collection of the NAS of Ukraine, it was found that southern breeding varieties have the highest resistance to drought. Therefore, 33 varieties were included for research, 19 of which were varieties of Kyiv selection and 14 varieties of southern selection.

It is known that the adaptation of plants to stress is controlled by a complex molecular genetic system that triggers a certain stress regulatory mechanism that provides homeostasis and protection against the breakdown of proteins and cellular components. In wheat, spare proteins are found in seeds that, when dried, produce aleurone grains when ripened [8].

Therefore, the level of drought resistance was determined in the investigated varieties in the early stages of germination of seeds on a solution of sucrose, which corresponds tij the pressure of 16 atm in laboratory conditions during 2015-2017. Dry seeds of 300 grains of each variety were selected, 
soaked in a sucrose solution of 16 atm in Petri dishes and germinated for 5 days in a thermo cabinet at $20-21^{\circ} \mathrm{C}$. The percentage of sprouted grains, which was determined by the number of grains that formed the minimum root length, was calculated after 7 days. The results of the survival of the seedlings or the number of living seedlings are presented in Fig. 2.

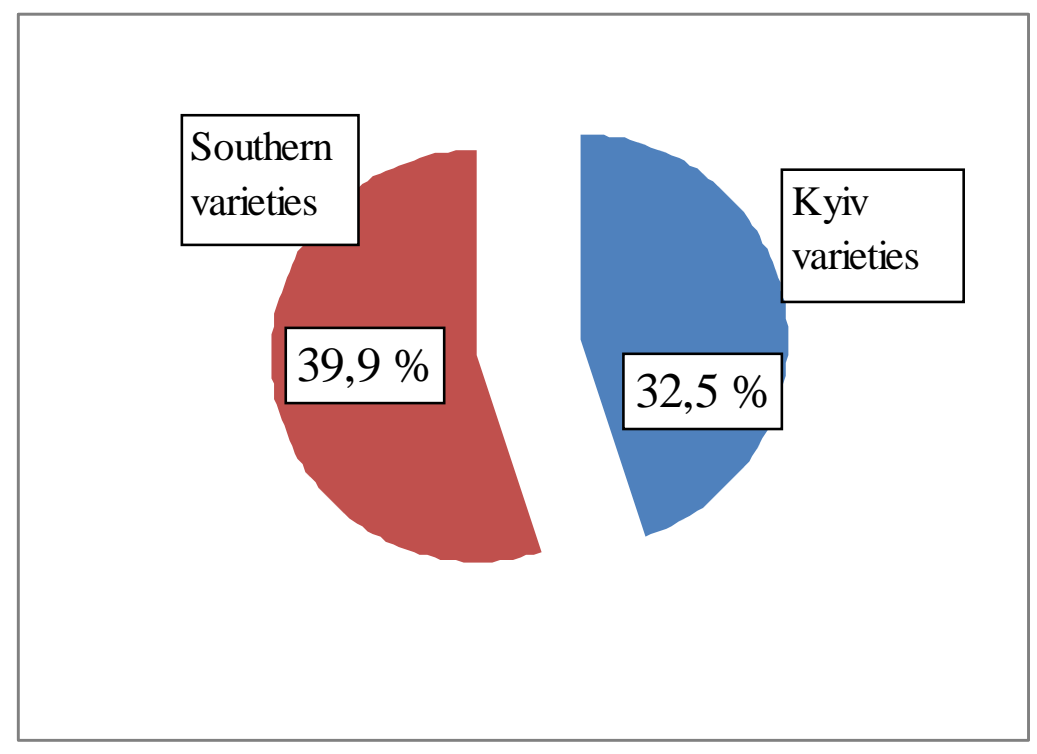

\section{Fig. 2. The average number of live seedlings in winter wheat varieties in determining the drought resistance}

It is proved that in the early stages of germination of wheat seeds on sucrose solution, which corresponds to the pressure of $16 \mathrm{~atm}$, the average level of drought resistance of the southern breeding varieties is $7.4 \%$ higher than in Kyiv breeding ones.

Researchers and breeders believe that drought is especially dangerous for winter wheat in the "critical period" that is a period of grain filling. Under the influence of deep soil drought, grain yields are most severely reduced when the drought occurs 5-7 days before mowing, as well as during the harvesting period [8]. Drought causes an increase in osmotic pressure and the concentration of cellular juice of cotton leaves [12]. Therefore, during the 2017-2019 harvesting period of the wheat varieties, the concentration of cellular juice was determined in the field in the flag leaf of the plants. 3-4 flag leaves were taken from the main stems and placed in plastic bags in the fields with the typical plants in the morning. Samples were immediately taken to the laboratory and analyzed. The results of determining the concentration of cellular juice are presented in table.

Concentration of cellular juice in winter wheat varieties in the coughing phase

\begin{tabular}{|c|c|c|c|}
\hline \multirow{2}{*}{ Breeding varieties } & \multicolumn{3}{|c|}{ The average concentration of cellular juice, \% $\% \mathrm{~S}_{\mathrm{p}}$} \\
\cline { 2 - 4 } & 2017 & 2018 & 2019 \\
\hline Kyiv & $13,0 \pm 2,3$ & $10,7 \pm 2,2$ & $13,5 \pm 2,3$ \\
\hline Southern & $14,8 \pm 2,4$ & $12,3 \pm 2,3$ & $15,1 \pm 2,5$ \\
\hline
\end{tabular}

The obtained data show that in the last three years the average concentration of cellular juice in the flag leaf of the varieties of Kyiv breeding during the phases of wheat heading was $2 \%$ lower than in those of the southern selection. Varieties of Kiev breeding such as Bohdana, Podolyanka, and Hospodarka were distinguished by the index of the concentration of cellular juice in the flag leaf during the mating phase at the level of the southern breeding varieties, and the varieties Natalka, Smuglyanka, and Darynka Kyivska exceeded their average by $1-2 \%$.

When comparing data of the level of drought resistance of varieties under the conditions of 20172018, determined at the early stages of germination of seeds on sucrose solution, there was established an authentic correlation $\eta \pm l_{95}=0,74 \pm 0,12$ with the concentrations of cellular juice of the flag leaf in the hatching phase by statistical analysis of the Student's criterion at a high probability level. Such a physiological aspect is used and taken into account in the diagnosis of winter wheat samples in field conditions on the basis of drought resistance in breeding practice.

But breeders pay great attention to the direct field assessment of the resistance to drought, considering it the most reliable. The main role in the overall evaluation of varieties for drought resistance is determined by the value of the yield. However, the estimation on the basis of the absolute value of 
the crop is not reliable in the dry years, due to the influence of other factors and genetically determined properties of the characteristic genotype in the formation of the crop. Therefore, the diagnosis of drought resistance of varieties was carried out in the period of abnormally hot and arid conditions in 2019 during the formation and filling of grain on the main wheat ear by the efficiency factor of the ear.

The wheat flowering phase was the starting point for the ear mass on June 3,2019 , and the full maturity phase was ending on July 17 . The ears of the main stem of the plants were selected in the morning and weighed on the scales in the field conditions. The weight of the main ear was measured 4 times and the earning factor of the ear was calculated 3 times during the coefficients of realization of spike productivity. The results of studies of the same varieties are presented in Fig. 4.

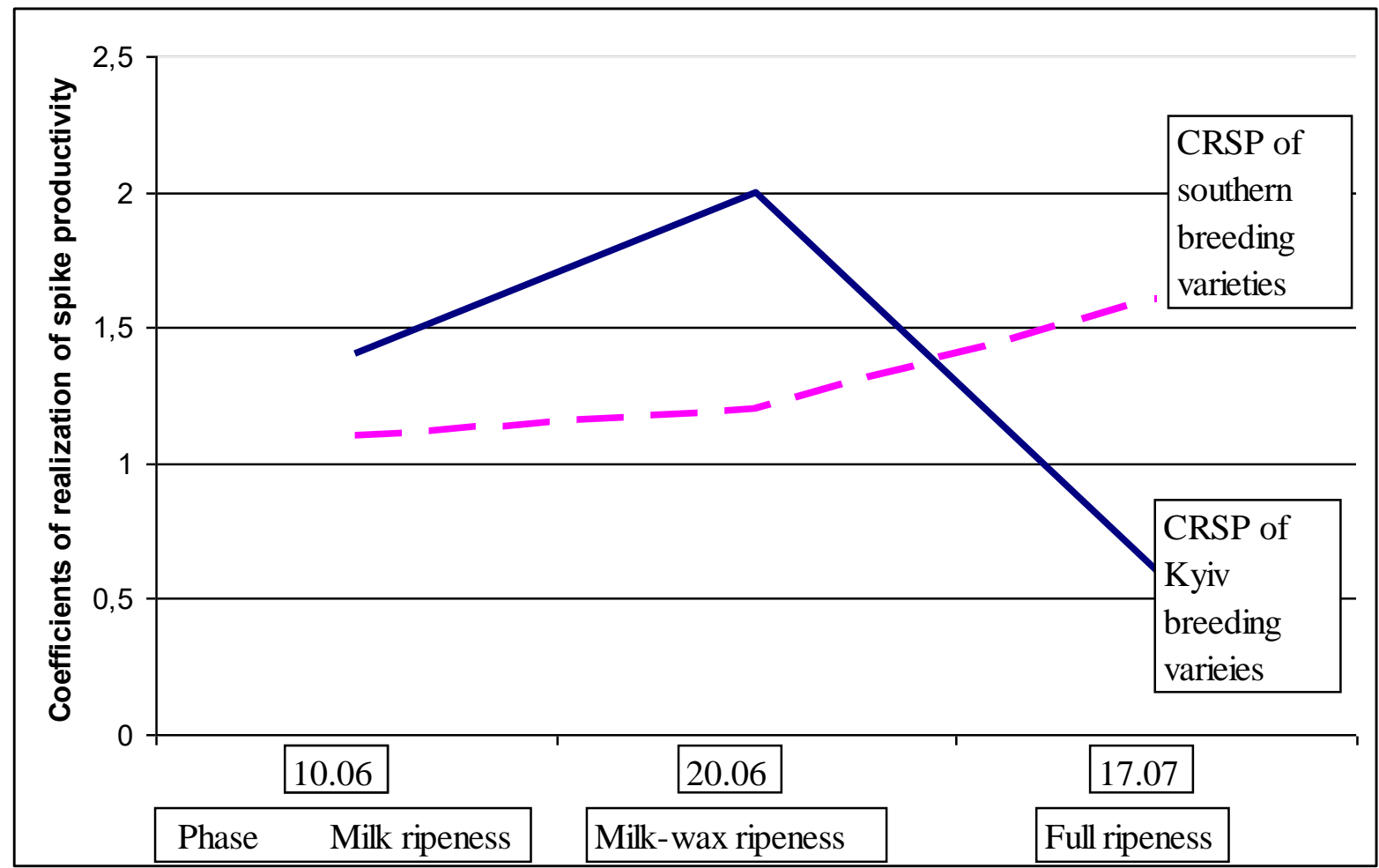

Fig. 4. Coefficients of realization of spike productivity of winter wheat varieties of Kyiv and Southern breeding in grain filling period, 2019

Obtained data show that the formation of the main crop of Kyiv breeding varieties occurs in the first half of the period of grain filling, and drought-resistant southern varieties realizy the productivity potential of the ear in the second half of that period.

It was found that Kyiv breeding varieties were $2.5 \%$ better realizing their genetically determined productivity potential by a factor of 4.0 than southern breeding varieties under climatic conditions of the 2019 grain filling period. Drought-resistant varieties of IPPG, NAS of Ukraine were selected for the high factor of realization of productivity potential of ear: Favorytka - 4,6; Bohdana - 5,4; Kalancha - 5,8 and Darunok Podillya - 6,1. The investigated varieties are involved in breeding programs for the creation of new high-yield and highly adaptable winter wheat starting material.

\section{Conclusions}

It is proved that the level of drought resistance of varieties has a strong relationship $r \pm I_{95}=0,74 \pm 0,12$ with the concentration of cellular juice of the flag leaf in the stage of wheat hatching in the early stages of germination of seeds on sucrose solution of 16 atm of wheat. It was found that Kiev breeding varieties realized their genetically determined potential of ear efficiency by $2,5 \%$ better with record abnormal heat and drought during the period of grain filling in 2019. Highly drought resistant and highly productive varieties of IPPG, NAS of Ukraine: Favorytka, Bohdana, Kalancha and Darunok Podillya are distinguished.

\section{References}

1. Morhun, V.V., \& Rybalko, O.I. (2017). Stratehiia henetychnoho polipshennia zernovykh zlakiv z metoiu zabezpechennia prodovolchoi bezpeky, likuvalno-profilaktychnoho kharchuvannia ta potreb pererobnoi promyslovosti [Strategy of genetical improving cereal crops for ensuring food security, therapeutic and preventive nutrition and the needs of the processing industry]. Bulletin of the NAS of Ukraine, 3, 54-64. [in Ukrainian]. 
2. Yermokhin, Yu.l. (2018). Diagnostika potrebnosti ozimoy pshenitsy $v$ udobreniyakh na osnove khimicheskogo analiza rasteniy [Diagnostics of needs of winter wheat for fertilizers based on the chemical analysis of the plants]. Electronic Science-Methodical Journal of Omsk SAU, 1 (12) January-March. URL: http://e-journal.omgau.ru/images/issues/2018/1/00494.pdf. - ISSN 24144066 [in Russian].

3. Amin, Fathi \& Tari, Barari (2016). Davood Effect of Drought Stress and its Mechanism in Plants. International Journal of Life Sciences, 10(1), P. 1-6.

4. Khomenko, L.O., \& Sandetska, N.V. (2018). Dzherela kompleksnoi stiikosti pshenytsi ozymoi (Triticum aestivum L.) u selektsii na adaptyvnist [Sources of complex resistance of winter wheat (Triticum aestivum L.) in selection for adaptability]. Plant Varieties Studyind and Protection, 14, 3, 270-276. doi: 10.21498/2518-1017.14.3.2018.145289 [in Ukrainian].

5. Foyer, C.H., \& Noctor, G. (2002). Oxygen processing in photosynthesis: regulation and signaling. New Phytol, 146, 359-388.

6. Monakhova, O.F., \& Chernyadev, I.I. (2002). Protective role of kartolin-4 in wheat plants exposed to soil drought. Appl. Biochem. Microbiol., 38, 373-380.

7. Reddy, A.R., Ramachandra, R.K., Chaitanya, V., \& Vivekanandan, M. (2004). Drought-induced responses of photosynthesis and antioxidant metabolism in higher plants. J. Plant Physiol., 161, 1189-1202.

8. Genkel, P.A. (Ed.). (1969). Fiziologiya selskokhozyaystvennykh rasteniy. Fiziologiya pshenitsy. [Physiology of agricultural plants. Physiology of wheat]. Moscow: University Press, T. 4. [in Russian].

9. Tkachyk, S.O. (Ed.). (2014). Metodyka provedennia ekspertyzy sortiv roslyn hrupy zernovykh, krupianykh ta zernobobovykh na prydatnist do poshyrennia $v$ Ukraini (PSP) [Methods of examination of plant varieties of crops, cereals and legumes for distribution in Ukraine]. Kyiv: NilatLTD [in Ukrainian].

10. Udovenko, G.V. (Ed.). (1988). Diagnostika ustoychivosti rasteniy k stressovym vozdeystviyam [Diagnostics of plant resistance to the stress impacts]. Leninrad: VIR. [in Russian].

11. Dospekhov, B.A. (1985). Metodika polevogo opyta (s osnovami statisticheskoy obrabotki rezultatov issledovaniy) [Methods of field experiment (with the basics of statistical processing of research results)]. 5th ed., suppl. and rev. Moscow: Agropromizdat [in Russian].

12. Kobylov, Y.T., Ergashov, A., \& Abdullayev, A.A. (2017). Indeksy fotosinteticheskoy produktivnosti rasteniy pshenitsy $v$ usloviyakh pochvennoy zasukhi [Indices of photosynthetical productivity of wheat plants in the soil drought conditions]. DAN RT, 60, 3-4, 189-193. [in Russian]. 